\title{
$605 \mathrm{Al}-\mathrm{Mg}-\mathrm{Si}$ 系合金の曲げ加工性
}

\author{
Bendability of Al-Mg-Si alloys \\ O即村友明（茨城大院）中武面也（荻城大）伊藤吾朗（茨城大） \\ Tomoaki IIMURA, Graduate Student,Ibaraki University \\ Naoya NAKATAKE,Student,Ibaraki University \\ Goroh ITOH,Ibaraki University
}

\begin{abstract}
Aluminum alloy sheets are attracting attention since they lighten an automobile body. Among them, some Al-Mg-Si alloys have already been applied to a part of automobile bodies because these alloys have hardenability during paint baking and do not cause a stretcher strain pattern. However, their bendability is significantly poor compared to that of steels. Therefore, in this paper, close microstructural observation has been made on the side surface as well as tension surface, in order to clarify the influence of the difference in the alloy composition, ie., amount of $\mathrm{Mg} 2 \mathrm{Si}$, amount of excess $\mathrm{Si}, \mathrm{Cu}$ addition, etc. Special care has been taken to the occurrence of the crack and unevenness. As a result, cracks were found to be prone to form when the amount of $\mathrm{MgzSi}$ or excess $\mathrm{Si}$ increased, although the increase in the amount of alloying element, particularly $\mathrm{Cu}$, caused grain refinement.
\end{abstract}

Key Words : Al-Mg-Si alloy, bendability, alloy composition, crack.

\section{1. 粕言}

近年、地球温暖化防止のために二酸化炭素排出量削娍が重 要な橦題となっている。この対策として自動車の二酸化岸素 排出量削娍が考えられている。排出量削娍の有効な方法とし て車体の柽量化が重要視されており、ボディのアルミニウム 合金化が期待されている。そして、望装焼付け硬化性を有す ることや、ストレッチャーストレイン模様が発生しないこと などの利点を生かして、Al-Mg-Si 系合金が一部自動車ボデ に道用されている。しかし、この合金は従来の鈵材に比へて 成形性(特に曲げ性)が劣るため、これまで曲げ加工性に関す る研究が行われてきたり。本研究では曲げ加工に伴う割れや

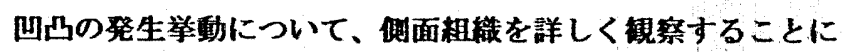
より、合金の化学組成の違いの䥺点から調へた。

\section{2. 封料および実㟲方法}

圾料は溶解・鋳造、均質化処理、熱間圧延、中間焼鈍、命 間压延のプロセスで製造された Al-Mg-Si 系合金の $1 \mathrm{~mm}$ 厚の 板材である。それらから長手方向が元の板幅力向となるよう に、15 $\times 35 \mathrm{~mm}$ の短冊状試験片を切出し、540 Cで $1 \mathrm{~h}$ 溶体 化処理し、空命の後、22〜25`Cで 7 d 自然時効処理を施し、 試料とした。合金の化学組成はTable 1 に示すように 5 種類 である。A2をべースとして MgzSi 量を增加させたものを A3、 的 0.7\%の過剩 Si を添加したものを A5 とし、A8は A3に Cu を添加し、A9は A2に約 0.4\%の過利 Si と Cuを添加したも のである。㲅れや山凸の発生举動の観察を容易にする目的で、 圾料の例面は鏡面に仕上げた。曲げ試験は、JISZ 2248に準 提し、内脚半径 $0.5 \mathrm{~mm}$ 、曲け角 $180^{\circ}$ で巻き付け法にて行っ た。その後、㑡面はもとより、張力面についても SEM で㓋 茨城講演会講演論文集（共催 日本機械学会関東支部・精密工学会, 協賛 日本塑性加工学会, 2002-9-13, 日立)
察した。

Table 1 Composition of alloy specimens used in this study in mass\%.

\begin{tabular}{|c|c|c|c|}
\hline $\mathrm{No}$ & $\mathrm{Mg}_{2} \mathrm{Si}$ & Excess $\mathrm{Si}$ & $\mathrm{Cu}$ \\
\hline $\mathrm{A} 2$ & 1.10 & - & - \\
\hline $\mathrm{A3}$ & 1.53 & - & - \\
\hline $\mathrm{A5}$ & 1.09 & 0.66 & - \\
\hline $\mathrm{A8}$ & 1.50 & - & 0.34 \\
\hline $\mathrm{A9}$ & 1.10 & 0.36 & 0.34 \\
\hline
\end{tabular}

\section{3. 実酸結果}

Fig.1に試料の湖面の SEM 写真を示す。割れは認められな かったが、結晶柆単位での凹凸が見られ、合金元素量が増加 するほど、特にCu 添加により結晶粒が榴かくなることがわ かる。 二の原因として、Mg2Si 量の増加や過剩 Si、Cu の添 加により、Mg2Si 化合物や Cuを含む化合物などが溶体化処 理時に末固溶状供で存在するようになり、溶体化処理中の柆 成長の妨げとなることが举げられる。

Fig.2 は試科の張力面の SEM 写真である。結晶粒単位の凹 凸については、Fig.1に示した側面の結果とほほ一致している。 しかし A3、A5においては凹凸だけでなく、明らかに割れが 発生している(矢用)。つまり、 $\mathrm{Mg} 2 \mathrm{Si}$ や過剩 Si の量を增加す ることにより割れを生じやすくなるといえる。また、割れは 柆界で発生し、破面上には析出物が存在するように見える。 
4. 参考文块

1）例えは，伊藤吾朗，伊萑伸英，鉿木孝佳，梅津俊太郎：

怪金属学会第 102 回春期大会满演概要, (2002), 239-240.

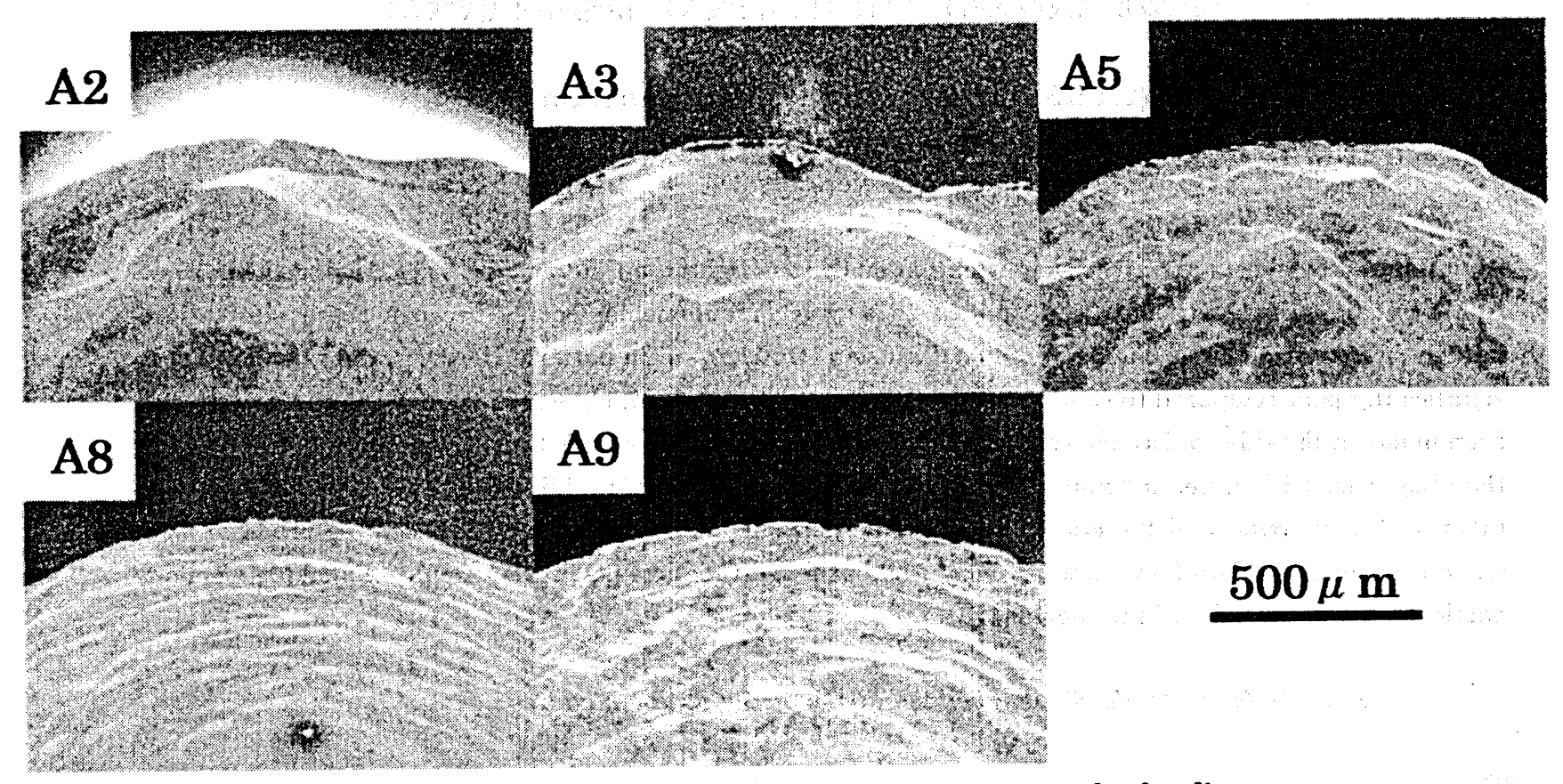

Fig.1 SEM micrographs of a side surface of specimens after bending.

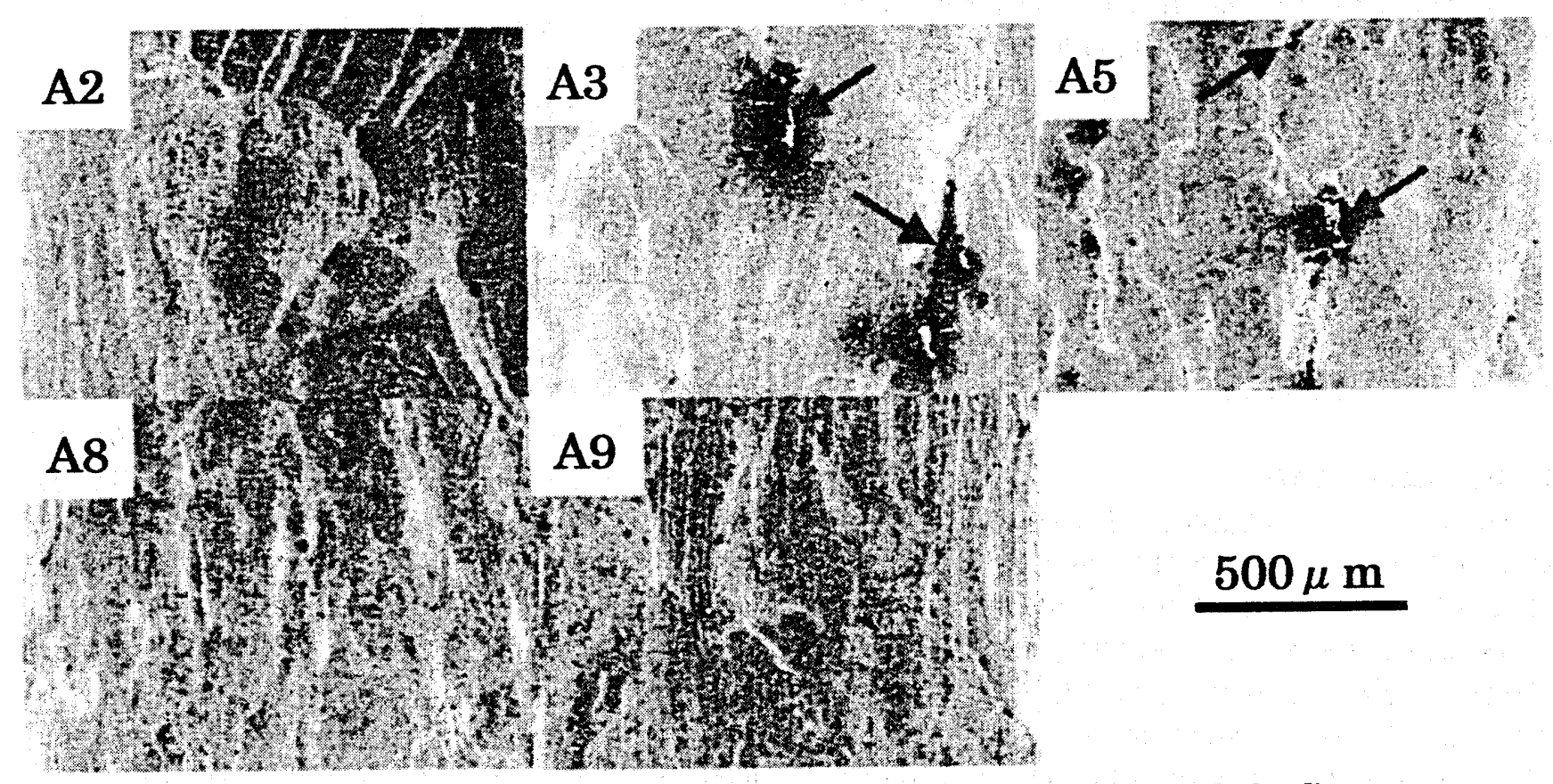

Fig.2 SEM micrographs of tension surface. Arrows indicate cracks formed by the bending. 